\title{
FEMININE SPIRITUAL HERMENEUTICS IN EASTER EGG AND MAULID EGG; \\ A Comparative Elaboration
}

\author{
Syamsul Asri \\ Indonesian Consortium for Religious Studies, \\ Gadjah Mada University \\ Bulaksumur, Caturtunggal, Depok, Sleman, Yogyakarta 5528 \\ Email: syamsulasri14@gmail.com
}

Abstract: The main focus of this paper, comparative elaboration of Easter egg in Orthodox Christianity in Eastern Europe and Maulid egg in southern Sulawesi, become the strategic field of female engagement with their communality. The very crucial element in this brief comparison is the obvious feminine quality of both Maulid egg and Easter egg, thus both of this socio-religious practices conducted, exercised, examined by female subjects in its primer state. I construct the feminine role in Maulid egg and Easter egg through three centripetal stages in which feminine subject articulate its self-definition and self-positioning in socioreligious landscape; garden, kitchen, and public ritual occupying public sphere, all of which reflect the strategic and irreversible role and self-articulation by feminine subjects.

Key words: Egg, Easter, Maulid, Hermeneutics, Feminine

\section{Introduction}

As an ordinary Muslim from remote area in east Bulukumba, South Sulawesi, I hardly have deep and elaborative contemplation about Maulid egg which served during annual commemoration of the birth of Prophet Muhammad saw. and play crucial role as sole signification for this event in my community until this day. Even though egg 
also appear in other occasion such as in entering new house rite, egg in Maulid has difference appearance both in more color and decoration. Indeed, Maulid in Tiro, my territory in eastern Bulukumba in which my parent's house located, Maulid without egg is not Maulid at all.

Maybe because the insufficient distance between me and the Maulid ritual become the major cause of my lack of meaning construction about Maulid egg. My one self and community already always living around this and that ritual so that it become too close for me to evaluate such kind of ritual practices. This situation, I hope, will be transcended by comparing Maulid egg with Easter egg in Christianity so that I could construe another meaning of Maulid egg which, maybe, already there in my community but in latent and potent stage.

I would like to compare, in this paper, how Easter egg in Orthodox Christianity in Eastern Europe and Maulid egg in southern Sulawesi become the strategic field of female engagement with their communality. The very crucial element in this brief comparison is the obvious feminine quality of both Maulid egg and Easter egg, thus both of this socioreligious practices conducted, exercised, examined by female subjects in its primer state. I construct the feminine role in Maulid egg and Easter egg through three centripetal stages in which feminine subject articulate its self-definition and selfpositioning in socio-religious landscape; garden, kitchen, and public ritual, all of which reflect the strategic and irreversible role and self-articulation by feminine subjects. 
In this paper I use and elaborate Victor Turner concept of root metaphor, in our case egg as root metaphor. Root metaphor relate to the axial, primer, all-embrace image by which social actors relate themselves in order to give, navigate, elaborate, share, evaluate meanings for their daily life. ${ }^{1}$ Without root metaphor, no society can exist. Jesus Cross and Imam Husain massacre in Karbala must be seen as root metaphor for Christian and Shia Muslim respectively. Here, egg both in Orthodox Christian`s Easter and Konjo Muslim `s Maulid play as root metaphor, around which meanings are convey, saturate, and lived by social actors.

\section{Easter Egg and Christian Orthodox Subject}

Even though many Christian today, indeed, are considering Easter egg as trivial decoration for Easter celebration, the little curiosity is all needed to answer why the Easter moment, as the biggest and most festive celebration among the Orthodox Christianity, never being separated from egg. ${ }^{2}$ This trivialization of Easter egg relate very deep with both official propaganda from the previous Communist regimes governing across eastern Europe and the condition of juggernaut capitalism which intend to exclude all things unfit to profit maximization. ${ }^{3}$

\footnotetext{
${ }^{1}$ Victor Turner, Dramas, Fields, and Metaphors; Symbolic Action in Human Society, Cornell University Press, Ithaca, 1974, p. 26-9

2Venetia Newall, Easter Egg, Folklore, Vol. 79, No. 4 (Winter, 1968), Taylor \& Francis, London, p. 276

${ }^{3}$ Venetia Newall, Easter Egg, Folklore, Vol. 80, No. 315 (Winter, 1967), Taylor \& Francis, London, p. 26
} 
Before long gone in Eastern Europe, before Communist regimes take over the socio-political sphere, especially before the Bolshevik Revolution in 1917, Easter event is celebrated as the biggest religious moment in a year, even bigger than Christmas itself. In this religious event, egg in many shape and material take the core visual space thus become the center of all Easter practices. ${ }^{4}$

From the word Eostra or Ostara, the shadowy Goddess figure cult from West Germanic tribes, Easter celebration has its root in pagan and Greek tradition, although Dr. Wildhaber, the Swiss authority on Easter lore insist that Christian Easter may not rooted in Eostra or Ostara cult. But one thing is obvious; the usefulness of egg as the major property in Easter has coming from non-Christian complicated elaboration, not only, for example, its relates to philosopher egg which commonly known as philosopher stone, but also Egg and its fertility cosmogonic myths may emerge from almost all over the world. ${ }^{5}$

Egg symbolizes the creation and resurrection of the world especially the human fate in this later will become complex and high philosophical and religious elaboration. Simple mind of most ancient tribe, when coming to provide the answer of the origin of the world and human, turns to egg as the obvious example of how complex life of organism coming from elementary foundation. ${ }^{6}$ Certainly, egg seen as

${ }^{4}$ Newall, Ibid, 1967, p. 28

${ }^{5}$ Newall, Ibid, 1967, p. 6

${ }^{6}$ Newall, Ibid, 1967, p. 3 
the mini and observable embodiment process of creation, and also, to some extent, resurrection in which immortality understood as the most basic human need. ${ }^{7}$ The round shape of egg tells about the uninterrupted state of human life, which death seen as a compulsory gate used as bridge to cross to another kind of life.

When comes to Orthodox Christian Easter event, often boiled red colored egg symbolize the blood of Jesus, appears to Easter observant as the promise of eternal Jesus, embodied in the hymn "Jesus Has Risen" declared by the priest and answered "Indeed Jesus Has Risen" by congregation a moment before these red eggs distributed or exchanged among them. ${ }^{8}$

Rumanian legend described how the Virgin Mary bring a basket full of boiled egg as offering to guardian soldier in charge of Jesus`s Cross. But the stoned heart of the soldier did not attend to her request and the basket remains under the bleeding feet of Jesus, turning the egg reddening. Red egg of Easter also signify the blood of Jesus given to us, the Christian and humanity at large, in which cosmic love, sacrifice and compassion celebrated as the most mighty force in universe.

Making, exchanging, eating, searching, tapping, crushing Easter egg magnify the spiritual and social presence and relevance of Jesus message. Egg and its symbols resonate

${ }^{7}$ Newall, Ibid, 1967, p. 14

${ }^{8}$ Newall, Ibid, 1968 , p. 272

${ }^{9}$ Newall, Ibid, 1967, p. 21 
the crucial relation between Jesus as the Source of Knowledge and Salvation with individual and its community as the grace receiver, in which, after exchanging and eating Easter egg, that individual and community transforms into new self, Jesuslike, full of love and compassion and thus paralleling the birth of the free and flying bird (symbol of human soul) from egg.

\section{Maulid Egg and Southern Sulawesi Muslim Subject}

Annually Maulid, the event of Prophet Muhammad saw. birthday, celebrated every 12 Rabiul Awal in Islamic lunar calendar, marks the one of the most anticipated event in Konjo society in southern Sulawesi, from which I descended. The character of Islamic society here is very Sufi-oriented thanks to Dato `Tiro, the Muslim preacher and propagator in $15^{\text {th }}$ century, which differentiate his preaching approach to another two Dato` (more figh and social order orientation exercised by Dato` Ri Bandang in Gowa-Tallo kingdom \& more philosophical orientation exercised Dato` Patimang Palopo/Luwuk society) thus relying heavily on syncretism between Islamic wisdom \& worldview and local practices \& articulation.

Similar to Easter celebration, Maulid decorated and imbued by red egg. Occupying the visual landscape of Maulid, red egg symbolizes the full potency of human soul toward perfection. Round shape of egg is seen as perfection form because it is not occupied by any corner resembling stop or pause i.e. death. 
Red coloring egg magnify the blood, the true sign of organic life surrounding the insignificant inanimate object, waiting to be touch by the barakah/grace of Prophet Muhammad through the reading, communally, of his parts of sirah nabawiyyah/historical accounts of stages of Prophet Muhammad life, especially his worldly birth event and his spiritual birth i.e. his appointment as God`s Messenger \& his ascending to heaven in order to receive the order of daily prayer. Grace of this communal reading is believed enters the eggs and thus sharing and eating it is rewarded as having high moral, social and spiritual consequences. ${ }^{10}$

Among other things such as healing and economic prosperity, one of the most anticipated of such consequences is to be born again, spiritually, as prophet-like, copy catting the insan kamil (perfect human being) quality of prophet Muhammad. ${ }^{11}$ Here love and knowledge of God and its most direct consequence i.e. love and knowledge about human and cosmos, become the major theme of Maulid-related practices, in which egg seen as the crucial locus of socio-spiritual meaning.

Because its hiddenness, the egg`s yolk is emphasized by Konjo tribe as the hidden knowledge of God bestowed upon God`s most closest servant, after which, s/he become

${ }^{10} \mathrm{~A}$ similar and highly connected notion/practice also maintained by Cikoang communities in coastal Takalar district, South Sulawesi, where Dato `Tiro`, believed to be first arrival at before going to Tiro area. See Muhammad Adlin Sila, Maudhu: $A$ Way of Union with God, Canberra, ANU Press, 2015, especially in chapter 5.

${ }^{11}$ Sachiko Murata, The Tao of Islam; A Sourcebook On Gender Relationship in Islamic Thought, SUNY Press, New York, 1992, h. 33-7 
both the servant and the friend (wali) of God, by which God maintain the cosmos and human affairs.

The central theme of Maulid egg is the fixed and specific relation between God, prophet Muhammad as God`s best wali and human soul. This triparted in form of three stages, must be seen as a necessarily track of human source (al-mabda) and its final home (al-ma ad), resembling, in my point of view, the central signification of Easter egg.

In this point, I would like to suggest that in Easter and Maulid cases, human soul is feminine quality in front of masculine Jesus and masculine Muhammad respectively. From here, feminine soul empowered by its masculine spouse in order to be masculine soul against its lusty body. At this point human soul becomes perfect; combining both the quality of feminine toward its God and masculine toward its body. Yet another stage must be mentioned; this perfect human soul becomes perfectly perfected by God in terms of God become its lover. Here, the one which loving and the other which loved could not be separated anymore even if can be distinguished. ${ }^{12}$

\section{Religious Egg and Subjectivity; Three Stages of Feminine Field of Meaning}

In previous segment, I write about feminine quality of human soul embodied in Easter egg and Maulid egg, both reflecting the rich bondage of human soul to its fullest perfection, envisioned but also exercised in daily activities and discourse performativity. Now this time I would like to

${ }^{12}$ Murata, Ibid, p. 191-8 
elaborate the gendered dimension of egg-related discourse in religious festival/celebration, namely Easter and Maulid. By doing so, I come up with the three stages of meaning field heavily relates to feminine subjectivity, yield in preparation, make up, cooking, exchanging, playing, and eating eggs in Easter and Maulid.

\section{Garden}

The first stage is the garden. Garden, and its religious equivalence, paradise, may coming from Persian, Firdawsi (Sanskrit and Indonsian: Firdaus) signify the intermediary state character of garden, in which two different things intermingled so that new entity, the third, could be risen. Paradise as garden, mediate The God's Throne and The Judgement Realm, could be understood as in-between stage of human soul quality being accepted and had been purified by God, of course after delivery previous stage of "egg-shell breaking", means going through self-perfection.

Both in pre-20 $0^{\text {th }}$ Century of Eastern Europe and contemporary Southern Sulawesi, garden is seen/experienced as the intermediary space between so many spaces; internal external, familiar - strange, home - street, known - unknown, coming things - departure things. It is the location for children playground, farming end-processing, and also home ground for hen to put its fresh egg. Garden is indeed the extension of one`s home so it could embrace also the animals, the plants, other people and eventually the cosmos. 
Hen`s egg found in the garden by mothers and daughters is a common practices not only in Eastern European and Southern Sulawesi communities, but across all pre-industrial society in which gender lived and shaped sexes to behave accordingly. From the garden which is an intermediary space, female actors bring in egg into the house, crossing over the fix boundary between spaces already mentioned. This crossing action is very strategic in terms of womanhood likely used to make unfamiliar/unknown become familiar/known so that gardening is indeed a reproductive and recreational practice.

\section{Kitchen}

Even though there has been huge challenge to the notion that kitchen is the most feminine space in the house, contemporary Muslim Konjo and Christian Orthodox societies across eastern Europe continue to understand kitchen as the female locus for participation in building and reshaping humankind and its world living in. In both societies, except in very rare case, the kitchen locates in the very back part of the house; this hiddenness quality of the kitchen relates heavily with the notion of personal, intimate, familiar things, handled by mothers and daughters.

This view nothing has to do with the sexist tendency to make kitchen as the only appropriate female space and make it unworthy for men, but contrary, kitchen relates to women physical womb, in terms of mothers and daughters keep nourishing their family, both in physical nutrition 
through healthy and desirable food and also through relaxing and delighting conversation and education which almost all takes place in kitchen. Of course there are so many good male cooker and kitchen handler, or vice versa but kitchen heavily considered as female zone and men only participated in it by permission is the obvious sign of kitchen as the space of female creation based on providing food for immediate family and community at large as its direct implication. Individual and communal quality of body and soul are determined by the quality of its female kitchen.

There are centrifugal and centripetal relations between garden and kitchen, and public zone as female spaces; each receives and gives from other, hence we simple could not ignore the crucial dimension played by women in all these zones. Here I am relates to the notion of lumpenproletariat whose social class position undermined \& exploited by the proletariat which in turn undermined \& exploited by the powerful bourgeois. ${ }^{13}$

Lumpenproletariat, although very strategic to diagnose specific power relation in certain societies such as western late post-industrial societies, it is not enough yet very obscure to use it as a lens to read the female strategic position in Orthodox Christian and Muslim Konjo communities, since women of these "field of practices" do not oppressed because and in the kitchen. Instead, kitchen (and beyond kitchen-

\footnotetext{
${ }^{13}$ Robert J. Young, Colonial Desire; Hybridity in Theory, Practice and Race, Routledge, London, 1995, P. 103-112
} 
related socio practices) become their major capital in negotiating with un-female power holder.

Kampidokang, a Konjo term, is reflecting the husband with very intruding manner into his wife kitchen affairs, in which such husband exercized his influencial in monetary and daily budgeting against his wife ability. Kampidokang husband, once he got the social stigma as one, he will be never put in any social or official public positions. This stigma spread through gossip not by his wife but by female relatives who come by occasionally.

Here we see the applying of gossip as the weapon of the weak, but once again I would like to argue that wives, mothers, daughters are very not weak in terms of they inherited, exercised, and play strategic role both in home and community because the significance of the kitchen.

\section{Public Ritual}

In previous part, indirectly I refer my perspective to Elizabeth Fiorenza`s (root) metaphor, bread not stone, in which this metaphor relates to the capacity of every religious hermeneutics to play healthy role in shape, build, and share the hospitality of religion based on scripture. ${ }^{14}$ Scripture is bread, by which religious readers and interpreters must covey that the basic and also final meaning of religion in text is precisely the capacity to nurture one self and others. The danger emerges if religious readers and interpreters covey that

${ }^{14}$ Elizabeth S. Fiorenza, Bread Not Stone; The Challenge of Feminist Biblical Interpretation, Beacon Press, 1995, p. xiii onward 
the basic and also final meaning of religion in text is precisely the capacity to torture one self and others, this is scripture as stone, used to hurt somebody else.

In our case, both in Easter and Maulid, egg is here to be shared together, not only among known/inside fellows, but also in order to welcome the guest, strangers and outside people. Easter and Maulid are always a public occasion, create public space and public sphere, where hospitality (religion as bread) exercised/celebrated and hostility (religion as stone) put to be gone. Festival and party alike seen in Easter and Maulid is an invitation to join the cosmic love and compassion in and by which God create humanity.

Victor Turner also has notion called liminality which I use in this paper because its powerful insight about religious public ritual and its capacity to maintain the social life. Liminality refers to the individual capacity to loosen its identity in pilgrimage and any religious public gathering. In pilgrimage, one social actors doing pilgrimage could not be distinguish solidly from another pilgrim. ${ }^{15}$ All evade into pilgrimage gravitational power usually based on holy shrine, sacrifice artefact, living person and symbol.

In my view, both in Easter and Maulid, egg plays significant role as liminal trigger in order to loosen individual (perceived) fix social identity. Red coloured egg seduce and argue that there is another self in which all Easter and Maulid attendant and observant must navigate themselves. Jesus-like

${ }^{15}$ Victor Turner, Ibid, p. 167-174 
in Easter and insan kamil in Maulid is other yet same self that must be gained in order to deliver the human soul perfection, just like egg crack its shell and emerge as bird. In this liminal process, one social actor expected to return to his/her social role, but with radical modification. Hospitality /"bread" and not hostility /"stone" must be lamented in his/her role in public life. I think this is the only parameter to judge either or not any kind of religious public event success or fails to deliver its promise and hopes.

In Eastern Europe, May Day has become the replacement of Easter event based on official propaganda by Communist Regimes, and after the downfall of Berlin wall the May Day become global phenomena. ${ }^{16}$ Even though Orthodox Christian continue to practice what they regard as way of life, today Easter egg seen as decoration in trivial sense, not only among them but across the globe. The significance of egg already almost forgotten by younger generation even though Easter Egg keep continue to appear in major pop culture event and artifact. The most recent case is in Ready Player One, a Hollywood movie directed by Stephen Spielberg (Universal Picture, 2018), in which a golden Easter egg played as a hidden treasure code (or root metaphor if I may) for entire movie awaiting to be found and solved.

Echoing ancient myth about searching and finding ultimate self in resembling with egg cracked its shell, Ready Player One, successfully depict the need of humanity to live

${ }^{16}$ Newall, Ibid, 1967, p. 28 
forever in eternal life, myth provided by religious resurrection, here one again we meet egg in terms of Phoenix dying in burnt and emerge again in an egg already lied before, surrounding by its burning ash.

But other fate happens in Konjo communities regarding their Maulid egg. Unlike Easter egg, Maulid continue to be understood as more than trivial decoration in annual religious events and gatherings. Freshly and strikingly, younger generation in Konjo perceive their Maulid egg as something symbolize other things, other things which are worthy to be celebrated, even though they rarely come up with complicated and elaborated understanding.

Perhaps this different fate between the eggs must be understood in the wider context of secularism (or desecularism) debate. Konjo Muslim and almost all other Muslim never entirely entrapped in sacred - profane debate. If "sacred cosmos" (with bracket sign) is understood as cosmos that made live by god and lived by people whose see everything in cosmos as purposive entities relates to god as god`s sign and thus also human being living in it as god sign denote to qualitative presence of god everywhere in the cosmos, then I will agree that most Indonesians live in and with it. ${ }^{17}$ Everywhere we look at around in Indonesian communities we see and feel the presence of myth (about the Prime Origin) and symbols (denote to Ultimate Purpose of Life) in architecture, in wedding ceremony, in life cycles rites

${ }^{17}$ B. Adeney-Risakotta, Living in the Sacred Cosmos, Chapter $1 \& 4$ onward, forth coming 
(from giving birth to buried the death ones), daily fashions, reproduction of spaces, etc.

But admitting the sacred (without bracket sign) is automate admitting the profane. This couple (sacred \& profane) is very Europe and Christian as its origins. Europe, or more specifically, the Christian Europe, knows best that their society fail to maintain singular power holder and thus separate it into two realm of powers (the Church and the State). The dominion of the Church is sacred \& the dominion of the State is profane. This notion later exported to the rest of the world by European colonialism and modernity. ${ }^{18}$

I like to highlight one (borrowed) critical evaluation for this notion of Indonesian living in sacred cosmos. The very fundamental notion about the sacred (and its mutual exclusiveness to the profane) is nowhere to be found in Indonesian worldview. Even the sacred as a word (translated to Indonesia as sakral) never been used by Indonesian as original word in Bahasa but derivatively from European language. Of course there are taboos but these taboo never rise meaning as the sacred in Eliadean perspective but more adequate to the notion of haram in Islamic perspective. ${ }^{19}$ Shahab Ahmed write,

"in short the putatively self-evident sacredprofane distinction that has been crucial to the

${ }^{18}$ Timothy Fitzgerald, The Ideology of Religious Studies, Oxford University Press, Oxford, 2000. p. 4-30

${ }^{19}$ See Mircea Eliade in Bernard Adeney-Risakotta (ed.), A Reader in Classical Theories for the Study of Religions in Indonesia Vol. III, ICRS, Yogyakarta, 2011. p. 648 in 73-8, please also see and compare with Gregory Baum, Religion and Alienation Ibid, p. 240 
construction of the modern category of "religion" is not similarly constitutive to Islam. The defining sacred versus profane distinction is somewhat confounded in the taxonomies of the discourses of Muslim, both by the relative weakness of the concept of "sacred" in the major language of Muslim, and especially by the absence of an indigenous term that designates "profane" 20

And this is not only relates to Islamic point of view but to almost all Indonesians as religious people.

In my view, the more adequate term to describe Indonesian and its cosmology (or cosmogonic consciousness) in general way is by applying the hierarchical presence of the Ultimate Truth/Beauty and the notion of holistic cosmos. For almost all Indonesians, market and office relate to the mosque \& church not in antagonistic, bipolar and mutual exclusiveness which is seem that the former are profane places and the latter are sacred places, but insist that both are the locus and stage for the presence of the Ultimate Truth/Beauty, both are embraced in holistic way by the allembracing Ultimate Presence, although the latter is more primer than the former.

This holistic cosmology is ever present for Indonesian, including me, a regular person that always worry about the "disenchanted" (with bracket sign) of Indonesian and their cosmos. Jaggernaut modernity is worried because not only it places human as subjected to market economy but also

${ }^{20}$ Sahab Ahmed, What Is Islam? The Importance of Being Islamic, Princeton University Press, Princeton, 2016, p. 207-208 
makes cosmos a giant commodity, resulting in terror and agony (starting from World War I onward). But my worry is limited to the actual reality that rationalization is auto/selfcritics \& self-alienating. With myth and symbol, Indonesian and all others religious people will be liberated again, in and with their "sacred cosmos". Not in the sense of compartment soul but in holistic yet hierarchical one.

\section{Another Stage; Cosmos Womb}

I am beginning this last section by quoting, in length, Venetia Newall notion about Daruma, a Japanese doll toy in relation with egg and our last stage of feminine field of meaning;

"In the symbolism of the human life cycle there is man life cycle t contradiction between life and death. Creation, life, death, and after-life fuse into one. 'Earth to earth, ashes to dust,' we say, in the Christian burial service; daruma which are found in every Japanese home, represent this thought. Toys or omocha, of which the daruma is one, are in many cases more than simple playthings. Often they are votive figures or charms with an ancient history, and they fulfil functions include bringing good luck, health and happiness to the owner and protecting him and his household from misfortune times. Such is the daruma - a small, round, egg-shaped with no limbs, the head and body formed all in one. It represents the Indian saint Bodhidharma, who went to China century A.D., where he founded the Ch'an Buddhist which Japanese Zen derives. According to popular legend, 
Bodhidharma meditated upon a mountain peak for 9 years and during this time his legs grew into the ground, his arms fused into his body. This shows how, in old age, we return to the egg whence we came"

This brings me to consider, centrifugally, about egg and its spiritual significance. After tracking, centripetally, the track of feminine field of meaning related to egg (from garden to kitchen, to public space) as embodiment of female practices and worldview, I assume that I need to go back to the universal qua ontological consideration about egg and its spiritual relevance.

\section{Concluding Remarks}

Here it seems to me that our earth is a giant egg, in which almost all God`s Drama have taken place. In turn, earth will be "cracked" and its "yolk" eventually will emerge as something never discoursed before, only experienced, by the prophets, sages, insan kamil and all persons in them gendered or gendering physical, psychological and cultural embodiment, is no longer a prime consideration.

I do not criticize gender studies and feminist perspective, what I would like to suggest is this critical paradigms deeply need to know where it stand and acknowledge its inherent boundaries, and consequently, supplying next critics. For example, May Day and its celebrated success in growing awareness and practices related to female working conditions is indeed must be championed, 
but May Day attendant also needs to look back its roots and reconsider not the price of modern May Day but the alternative May Day in which symbol, myth or simple hymn of free price tag cosmos is still insight.

To be considered in this broader context, the world as the cosmos womb, gender, sex and social position became more and more meaningless at worst or meaningful but not in the center spot at best, precisely because the focus of consideration is no longer about humane and its humanism, but entire planet and entire beings (in Islamic thought, cosmos is defined precisely as everything other than God), in which male and female play role, a role may or may not significant. In this regard, I conclude that if there is such a kind of religious egg, then it must be rooted in cosmos as God`s sign, in and through which religious readers refers back herself. ${ }^{21}$

\section{Bibliography}

Adeney-Risakotta, Bernard. (ed.), A Reader in Classical Theories for the Study of Religions in Indonesia Vol. III, ICRS, Yogyakarta, 2011.

Baum, Gregory. Religion and Alienation; A Theological Reading of Sociology, Paulist Press, New York, 1975.

${ }^{21}$ Murata, Ibid, p. 10-4 
Fiorenza, Elizabeth, S. Bread Not Stone; The Challenge of Feminist Biblical Interpretation, Beacon Press, 1995

Fitzgerald,Timothy. The Ideology of Religious Studies, Oxford University Press, Oxford, 2000.

Newall, Venetia. Easter Egg, Folklore, Vol. 79, No. 4 (Winter, 1968), Taylor \& Francis, London, 1968

Newall, Venetia. Easter Egg, Folklore, Vol. 80, No. 315 (Winter, 1967), Taylor \& Francis, London, 1967

Murata, Sachiko. The Tao of Islam; A Sourcebook On Gender Relationship in Islamic Thought, SUNY Press, New York, 1992

Sahab, Ahmed. What Is Islam? The Importance of Being Islamic, Princeton University Press, Princeton, 2016.

Sila, Muhammad Adlin. Maudhu: A Way of Union with God, Canberra, ANU Press, 2015

Turner, Victor. Dramas, Fields, and Metaphors; Symbolic Action in Human Society, Cornell University Press, Ithaca, 1974. Young, Robert J. Colonial Desire; Hybridity in Theory, Practice and Race, Routledge, London, 1995. 